How to cite this paper:

Tunku Badariah Tunku Ahmad, Nordin, M.S., Nordin Abd Razak, Mohd Burhan Ibrahim \& Joharry Othman (2017). Pertalian antara pengalaman masteri dengan efikasi kendiri guru: Regresi-meta kajian keratan lintang. Malaysian Journal of Learning and Instruction (MJLI), 14 (2), 247-269.

\title{
PERTALIAN ANTARA PENGALAMAN MASTERI DENGAN EFIKASI KENDIRI GURU: REGRESI-META KAJIAN KERATAN LINTANG
}

\section{(THE RELATIONSHIP BETWEEN TEACHERS' MASTERY} EXPERIENCE AND TEACHER SELF-EFFICACY: A METAREGRESSION OF CROSS-SECTIONAL STUDIES)

\author{
${ }^{1}$ Tunku Badariah Tunku Ahmad, ${ }^{2}$ Mohamad Sahari Nordin, \\ ${ }^{3}$ Nordin Abd Razak, ${ }^{4}$ Mohd Burhan Ibrahim \& ${ }^{5}$ Joharry Othman \\ ${ }^{1,2,4,5}$ Kulliyyah of Education, \\ International Islamic University Malaysia \\ Kuala Lumpur, Malaysia \\ ${ }^{3}$ School of Educational Studies, Universiti Sains Malaysia, Malaysia
}

Corresponding author: msahari@iium.edu.my

\begin{abstract}
ABSTRAK
Tujuan - Analisis-meta ini pertamanya bertujuan menentu sah kekuatan pertalian (ES) antara pengamalan masteri dengan efikasi kendiri guru. Kedua, kajian ini juga meninjau faktor moderator yang mungkin mempengaruhi ES tersebut.

Meodologi - Data analisis adalah bersumberkan sejumlah 26 kajian emperis terdahulu yang pada keseluruhannya melibatkan penyertaan 10,752 orang guru dengan berasaskan kriteria pemilihan konvensional. Untuk mengesan variabel moderator, prosedur regresi-meta telah digunakan.
\end{abstract}


Dapatan - Keputusan analisis-meta menyokong jangkaan bahawa pengalaman masteri mempengaruhi efikasi kendiri guru secara positif. Juga, sifat sampel, instrument mengukur efikasi kendiri guru dan budaya lokasi tempat bertugas secara kolektif berperanan sebagai moderator dalam mempengaruhi kekuatan pertalian pengalaman masteri-efikasi kendiri guru.

Signifikan-Hasil kajian menyumbangkan kepada pemahaman dan penyelidikan dalam bidang kognitif sosial dan efikasi kendiri. Seterusnya, terdapat implikasi praktikal yang wajar diambil kira oleh pembuat dan pelaksana dasar yang berkaitan dengan pembangunan professional guru.

Kata Kunci:Efikasi Kendiri Guru; Pengalaman Menguasai Kepakaran; Latihan Dalam Perkhidmatan; Analisis-Meta; Budaya Kerja.

\begin{abstract}
Purpose -The objective of the meta-analysis was first to substantiate the magnitude of the effect size (ES) of the relationship between mastery experience and teacher self-efficacy. Second, the meta-analysis was also aimed to search for the research characteristics that moderate the mastery experience-teacher efficacy relationship.
\end{abstract}

Methodology - A total of 26 original studies, involving 10,752 teachers was included in the meta-analysis. To identify the moderators, the study applied meta-regression procedure.

Findings - The results supported the expectation that mastery experience positively influences teacher self-efficacy. Collectively sample charactistic, self-efficacy measure and work culture impacted the variability of the effects size.

Significance - The findings add understanding about teacher selfefficacy. The findings also offer practical implications to researchers on 
teacher self-efficacy, and policy maker and administrators of teacher professional development programs.

Keywords: Teacher Self-Efficacy, mastery experience, in-service training, meta-analysis, work culture. 


\title{
PERTALIAN ANTARA PENGALAMAN MASTERI DENGAN EFIKASI KENDIRI GURU: REGRESI-META KAJIAN KERATAN LINTANG
}

\section{(THE RELATIONSHIP BETWEEN TEACHERS' MASTERY EXPERIENCE AND TEACHER SELF-EFFICACY: A META-REGRESSION OF CROSS-SECTIONAL STUDIES)}

\author{
${ }^{1}$ Tunku Badariah Tunku Ahmad, ${ }^{2}$ Mohamad Sahari Nordin, \\ ${ }^{3}$ Nordin Abd Razak, ${ }^{4}$ Mohd Burhan Ibrahim \& \\ ${ }^{5}$ Joharry Othman \\ 1,2,4,5 Kulliyyah of Education, \\ International Islamic University Malaysia \\ Kuala Lumpur, Malaysia \\ ${ }^{3}$ School of Educational Studies, Universiti Sains Malaysia, \\ Malaysia
}

Corresponding author: (msahari@iium.edu.my)

\begin{abstract}
ABSTRAK
Tujuan - Analisis-meta ini pertamanya bertujuan menentu sah kekuatan pertalian (ES) antara pengamalan masteri dengan efikasi kendiri guru. Kedua, kajian ini juga meninjau faktor moderator yang mungkin mempengaruhi ES tersebut.

Meodologi - Data analisis adalah bersumberkan sejumlah 26 kajian emperis terdahulu yang pada keseluruhannya melibatkan penyertaan 10,752 orang guru dengan berasaskan kriteria pemilihan konvensional. Untuk mengesan variabel moderator, prosedur regresi-meta telah digunakan.

Dapatan - Keputusan analisis-meta menyokong jangkaan bahawa pengalaman masteri mempengaruhi efikasi kendiri guru secara positif. Juga, sifat sampel, instrument mengukur efikasi kendiri guru dan budaya lokasi tempat bertugas secara kolektif berperanan sebagai
\end{abstract}


moderator dalam mempengaruhi kekuatan pertalian pengalaman masteri-efikasi kendiri guru.

Signifikan-Hasil kajian menyumbangkan kepada pemahaman dan penyelidikan dalam bidang kognitif sosial dan efikasi kendiri. Seterusnya, terdapat implikasi praktikal yang wajar diambil kira oleh pembuat dan pelaksana dasar yang berkaitan dengan pembangunan professional guru.

Kata Kunci:Efikasi Kendiri Guru; Pengalaman Menguasai Kepakaran; Latihan Dalam Perkhidmatan; Analisis-Meta; Budaya Kerja.

\begin{abstract}
ABSTACT
Purpose-The objective of the meta-analysis was first to substantiate the magnitude of the effect size (ES) of the relationship between mastery experience and teacher self-efficacy. Second, the meta-analysis was also aimed to search for the research characteristics that moderate the mastery experience-teacher efficacy relationship.
\end{abstract}

Methodology-A total of 26 original studies, involving 10,752 teachers was included in the meta-analysis. To identify the moderators, the study applied meta-regression procedure.

Findings-The results supported the expectation that mastery experience positively influences teacher self-efficacy. Collectively sample charactistic, self-efficacy measure and work culture impacted the variability of the effects size.

Significance-The findings add understanding about teacher selfefficacy. The findings also offer practical implications to researchers on teacher self-efficacy, and policy maker and administrators of teacher professional development programs.

Keywords: Teacher Self-Efficacy, mastery experience, in-service training, meta-analysis, work culture.

\title{
PENGENALAN
}

Efikasi kendiri disifatkan sebagai unsur teras yang menunjangi keyakinan dan menggerakkan tingkah laku (Bandura, 1977). Menurut 
Bandura, efikasi kendiri berperanan menentukan kesanggupan dan kecekalan seseorang untuk menyempurnakan tugas yang sarat dengan kesukaran dan halangan. Ia merupakan konstruk psikososial yang mempengaruhi aspirasi, matlamat dan motivasi setiap individu, termasuk guru. Malahan kini efikasi kendiri diperakukan sebagai salah satu petunjuk penting kualiti seseorang guru dan juga sesuatu sistem pendidikan. Lantas perbandingan kualiti sistem pembelajaran dan pengajaran di peringkat global turut mengukur dan menilai konstruk tersebut. Perkara ini dapat dilihat misalnya dalam kajian berkala, Teaching and Learning International (TALIS) yang dilakukan oleh OECD sejak 2008, di samping ujian Trends in International Mathematics and Science Study (TIMMS) (Martin, Mullis, Foy, \& Stanco, 2012).

Efikasi kendiri guru dikupas sebagai pertimbangan, ekspektasi dan keyakinan seseorang guru mengenai keupayaan dirinya mengawal suasana dan proses pembelajaran dan pengajaran (Pajares, 1992). Efikasi kendiri guru adalah konstruk mental yang mendasari keputusan dan tindak tanduk profesional seseorang guru. Guru yang mempunyai efikasi yang tinggi sanggup menerima tugas yang mencabar, tekun melaksanakannya dan sabar dengan kerja-kerja yang banyak menelan masa dan membanting kudrat (Bandura, 1977; Salomon, 1984). Guru berefikasi tinggi menilai kejayaan atau kegagalan pelajar dari sudut tindak-tanduk pembelajaran dan pengajaran yang berada dalam liputan kawalannya (Guskey, 1988; Howardson \& Behrend, 2015; Tschannen-Moran, Hoy, \& Hoy, 1998). Maka tidak hairanlah apabila efikasi kendiri guru mampu menggerakkan pembelajaran dan pengajaran ke aras yang lebih tinggi.

Sejak konsep ini diperkenalkan, efikasi kendiri guru semakin diberi tumpuan dalam penyelidikan mengenai keberkesanan pembelajaran dan pengajaran. Penemuan daripada pelbagai kajian bebas tekal membuktikan bahawa efikasi kendiri guru mempengaruhi inovasi dalam pengajaran (Guskey, 1988; Ghaith \&Yaghi, 1997), penilaian guru oleh rakan sejawat, penyelia dan nazir (Tschannen-Moran \& Hoy, 2007) Trentham, Silvern, \& Brogdon, 1985), dan komitmen kerja (Zee \& Kooman, 2016). Sebaliknya, sifat ini ditemui mempunyai pertalian songsang dengan tekanan dan burnt out (Shoji, Cieslak, Smoktunowicz, Rogala, Benight, \& Luszczynska, 2015). Guru yang melaporkan efikasi kendiri yang rendah didapati 
dihambat dengan isu-isu keberkesanan pengajaran, kepuasan dan tekanan kerja (lihat, misalnya Betoret, 2006).

Selain itu, efikasi kendiri juga mempunyai pertalian positif dengan pencapaian pelajar (Anderson, Greene, \& Loewen, 1988; Klassen \& Tze, 2014), motivasi pelajar (Midgley, Feldlaufer, \& Eccles, 1989) dan sikap pelajar terhadap sekolah (Miskel, McDonald, \& Bloom, 1983; Anderson, Greene, \& Loewen, 1988; Ashton \& Webb, 1986; Bandura, 1997; Yoo, 2016). Sorotan himpunan ilmu secara sistematik dan analisis-meta terdahulu mengukuhkan telahan Bandura mengenai efikasi kendiri guru (Klassen, Tze, Betts, \& Gordon, 2011; Klassen \& Tze, 2014; Shoji et al., 2015; Zee \& Kooman, 2016).

Namun, kita tidak begitu memahami punca perbezaan tahap efikasi kendiri dalam kalangan guru (Klassen et al., 2011; Klassen \& Tze, 2014; Kleinsasser, 2014; Morris et al., 2016). Walau pun data empiris mengenai faktor penentu, yang disebut sumber efikasi kendiri guru (Bandura, 1997) semakin banyak terkumpul, belum terdapat rumusan yang jelas tentang sifat dan kekuatan faktorfaktor atau sumber-sumber tersebut. Malahan terdapat penemuan kajian yang bercanggah. Di satu pihak terdapat penemuan yang menyokong impak positif pengalaman masteri-misalnya, menerusi latihan perguruan dan program pembangunan profesional guru-ke atas efikasi kendiri (Cadungog, 2015; Cantrell \& Hughes, 2008). Kajian-kajian lain pula mendapati tiadanya sebarang pertalian (Yenice, 2009). Malahan terdapat juga kajian yang menemukan kesan program pembangunan profesional yang negatif (Woolfson \& Brady, 2009; Yeo, 2008).

Ketidaktekalan sedemikian mungkin berpunca daripada reka bentuk penyelidikan. Kelainan makna dan pengukuran efikasi kendiri, sifat sampel, lokasi kajian yang diwarnai oleh budaya kerja yang tersendiri dan prosedur analisis data mudah menghasilkan keputusan berbeza. Maksudnya mungkin wujud variabel moderator yang turut berinteraksi dan mempengaruhi arah dan kekuatan pertalian pengalaman masteri dengan efikasi guru. Untuk itu, analisis-meta diperlukan bagi mencari dan mengenalpasti moderator tersebut bagi menghasilkan rumusan pertalian yang jelas. Pemahaman tentang faktor moderator, khususnya sifat-sifat kajian yang mempunyai kesan ke atas kekuatan pertalian itu adalah diperlukan. 
Untuk menangani kekangan pemahaman, analisis-meta yang dilaporkan di sini bertujuan menggabung dan meringkaskan data daripada pelbagai kajian bagi mengenalpasti dan menilai pertalian antara efikasi kendiri guru dengan pengalaman menguasai kepakaran. Analisis-meta ini juga meneroka sifat-sifat kajian empiris lepas yang mungkin menjadi moderator pertalian kausal itu. Ini sesuai dilakukan kerana prosedur analisis-meta mampu menggabung, mencerakin dan mencerna himpunan data yang besar dan pelbagai. Dengan itu, rumusan mengenai pertalian antara pengalaman masteri dengan efikasi kendiri tidak sekadar ditentukan oleh keputusan ujian hipotesis. Pendek kata, penemuan daripada analisis-meta mempunyai tahap tentu sah yang tinggi.

Dua soalan kajian yang mendasari analisis-meta ini adalah seperti yang berikut:

1. Apakah arah dan kekuatan pertalian (ES) antara iaitu pengalaman masteri dengan efikasi kendiri guru?

2. Adakah pengalaman mengajar dalam kalangan sampel mengikut tahap sekolah, lokasi kajian dan pengukuran efikasi kendiri berfungsi sebagai faktor moderator yang mempengaruhi kekuatan pertalian antara pengalaman masteri dengan efikasi kendiri guru?

\section{Sumber dan Moderator Efikasi Kendiri Guru}

Pemikiran dan penyelidikan tentang sumber atau penentu efikasi guru banyak didasari oleh teori kognitif sosial yang dipelopori oleh Bandura (1977). Bandura membayangkan terdapat empat sumber atau faktor penentu efikasi kendiri guru, iaitu pengalaman vikarius, dorongan lisan, keadaan emosi dan afektif, dan pengalaman masteri. Pengalaman vikarius bermaksud perubahan keyakinan profesional guru setelah dia memerhatikan kejayaan atau kegagalan guru lain melakukan sesuatu tugas sasaran. Dorongan lisan pula ditakrifkan sebagai galakan, pujukan atau pujian rakan sejawat atau pihak yang berpengaruh. Keadaan emosi dan aspek afektif lain merujuk kepada keadaan psikologi guru ketika berhadapan dengan sesuatu tugas. Misalnya minat atau perasaan teruja, atau sebaliknya perasaan tertekan atau keletihan boleh mempengaruhi tahap efikasi kendiri guru. Akhir sekali, Bandura menjangkakan bahawa pengalaman masteri, iatu pengamalan melakukan prestasi sasaran di masa-masa lepas juga mempengaruhi tahap efikasi kendiri guru. 
Pengalaman masteri dikategorikan sebagai penentu efikasi yang paling dominan. Pengalaman tersebut merangsang guru untuk merenung, menilai, dan membuat jangkaan dan keputusan samada sanggup melakukan sesuatu tugas sasaran. Bandura (1977) meramalkan bahawa, "successes raise mastery expectations; repeated failures lower them, particularly if the mishap occurs early in the course of events" (p. 195). Maksudnya, efikasi kendiri terbina apabila guru merasa berjaya menyempurnakan tugas pedagogi sasaran (Ghanizadeh \& Moafian, 2011; Ransford et al., 2009), kepuasan dengan prestasi profesionalnya (Tschannen-Moran \& Hoy, 2002) dan kepuasan berkaitan hubungan profesional dengan pelajar (Yenice, 2009). Juga, pendekatan pembelajaran dan pengalaman masteri yang didapati mempunyai korelasi yang positif dengan efikasi kendiri guru (Swee-Choo, Kung-Teck, \& Osman, 2012). Oleh itu, pendidikan dan program pembangunan profesional berpotensi besar membekalkan pengalaman masteri yang kekal menyegarkan efikasi kendiri guru. Kursus dalam perkhidmatan yang kaya dengan berbagai-bagai pengalaman masteri boleh meningkatkan kepakaran guru. Seterusnya mengukuh keyakinan, kesanggupan, kompetensi pedagogi, keupayaan membina ilmu yang bermakna dan kesediaan untuk memikul tugas dan tanggungjawab baru (Nordin, 2001; Ross $\&$ Bruce, 2007).

Bercanggah dengan telahan tersebut, kajian-kajian empiris jelas menunjukkan penemuan yang bercampur-campur. Kajian terdahulu banyak menerbitkan penemuan seperti yang dijangka, iaitu pengalaman masteri menghasilkan kesan positif ke atas efikasi kendiri guru. Namun, banyak juga penemuan lain yang membuktikan tidak wujudnya perkaitan yang signifikan; malah terdapat pertalian songsang antara pengalaman masteri dengan efikasi kendiri guru. Hal ini berkemungkinan disebabkan oleh sifat-sifat yang berbeza antara kajian, baik daripada segi reka bentuk, sampel kajian, instrumen mengukur efikasi kendiri guru dan juga budaya kerja guru di lokasi yang berlainan. Semua ini berpotensi berperanan sebagai moderator yang berinteraksi mempengaruhi pertalian pengalaman masteri-efikasi kendiri guru.

Satu daripada sifat kajian yang berpotensi berfungsi sebagai moderator ialah sifat sampel kajian. Sampel yang terdiri daripada responden yang mempunyai pengalaman yang luas dan pelbagai mampu menghasilkan tahap efikasi kendiri yang tinggi (lihat 
misalnya, Soodmand, Rahimi, Ghonchehpourc, \& Saedpanahc, 2015). Kepelbagaian pengalaman mengajar di beraneka jenis dan peringkat sekolah seharusnya meningkatkan efikasi kendiri guru. Selain kepelbagaian pengalaman, pengalaman masteri-efikasi kendiri guru juga turut bergantung pada budaya kerja (Klassen et al., 2011; Oettingen, 1995; Pajares, 2007; Torres, 2016). Dalam kalangan guru yang bertugas di lokasi yang budayanya bersifat kolektivis, iaitu yang dikatakan wujud dalam kalangan guru di benua Asia, budaya kekitaan adalah tinggi dan ini mengukuhkan pertalian antara pengalaman masteri dengan efikasi kendiri. Sebaliknya oleh sebab guru-guru di negara barat lebih mengutamakan norma, ekspektasi dan amalan individualistik, maka faktor budaya mungkin tidak mempengaruhi atau mempunyai kesan negatif ke atas kekuatan pertalian (Oettingen, 1995).

\section{KAEDAH ANALISIS-META}

Tinjauan ke atas kajian kuantitatif ini menggunapakai pendekatan analisis-meta. Data yang dianalisis-meta adalah bersumberkan laporan-laporan kajian terdahulu yang memenuhi kriteria saringan dan pemilihan yang dibentangkan seperti berikut.

\section{Kriteria Saringan Memilih Kajian Untuk Analisis-Meta}

Analisis-meta ini menggunakan tujuh kriteria yang dicadang oleh Lipsey dan Wilson (2001) untuk menentukan samada sesuatu kajian empiris tertentu dipilih atau tidak dipilih. Pertama, setiap kajian mesti melaporkan pertalian kuantitatif antara pengalaman menguasai kepakaran dengan efikasi kendiri guru. Kedua, sampel kajian mesti terdiri daripada guru yang bertugas di sekolah, iaitu samada di sekolah rendah atau sekolah menengah. Ketiga, kajian hanya diterima untuk dianalisis-meta jika terdapat pengukuran yang jelas bagi pengalaman penguasaan kepakaran jelas diukur (contohnya, kursus dalam perkhidmatan; kepuasan mengajar) dan petunjuk efikasi kendiri guru (misalnya, efikasi pengajaran; efikasi menggunakan strategi pengajaran). Keempat, kajian itu mesti mempunyai maklumat yang cukup bagi membolehkan kekuatan pertalian dirumus, iaitu magnitud atau kekuatan kesan (ES) pengalaman menguasai kepakaran. Kelima, hanya kajian-kajian yang dilaporkan dalam bahasa Melayu atau Bahasa Inggeris yang 
diteliti. Keenam, kajian diambilkira jika diterbitkan selepas tahun 1977, iaitu setelah Bandura memperkenalkan konsep efikasi kendiri. Akhir sekali, untuk menangani isu kesan file-drawer, analisis-meta ini meneliti semua laporan samada yang diterbit dan juga yang tidak diterbitkan dalam jurnal berwasit.

Variabel kriterion, iaitu angkubah bergantung dalam analisis-meta ini ialah efikasi kendiri guru yang ditakrifkan sebagai kesanggupan atau keyakinan guru dengan keupayaan dirinya menggubal dan melaksanakan tugas-tugas mengajar (Bandura, 1997). Definisi ini meliputi konstruk-konstruk yang diukur menerusi efikasi pengajaran peribadi (Gibson \& Dembo, 1984), keyakinan diri dalam pengajaran (Van Acker, 2013), efikasi kendiri dalam tugas-tugas tertentu, misalnya dalam hal mendapatkan penyertaan pelajar, mengurus kelas, dan menggunakan strategi-strategi pengajaran (TschannenMoran \& Hoy, 2001), keyakinan mengajar sains (Riggs \& Enochs, 1990), dan pengajaran inklusif (Sharma, Loreman, \& Forlin, 2012). Dua konstruk lain yang berkaitan, iaitu efikasi umum mengajar (general teaching efficacy; Gibson \& Dembo, 1984) and efikasi kolektif guru (collective teacher efficacy; Goddard, Hoy, \& Hoy, 2000) tidak diambilkira dalam analisis-meta ini. Ini disebabkan oleh makna dan pengukuran kedua-dua konstruk tersebut sarat dengan keyakinan tentang keupayaan guru secara kumpulan, dan bukan dirinya sendiri untuk mengubah pembelajaran dan pengajaran.

\section{Prosedur Pencarian dan Pengkodan Laporan}

Untuk mendapatkan cakupan yang lengkap, meluas dan bebas bias, prosedur semakan sistematik dilakukan untuk mencari, menyaring dan menyimpan laporan-laporan kajian-kajian terdahulu. Prosedur ini dimulakan dengan langkah mengenalpasti kajian-kajian sasaran menerusi pencarian dalam pangkalan-pangkalan data Education Resource Information Center (ERIC), ProQuest Education Journal, ProQuest Dissertation and Theses Global, and SCOPUS menerusi carian web. Beberapa kata kunci berkaitan pengalaman masteri dan efikasi kendiri guru digunakan dalam proses mencari, iaitu: efikasi kendiri guru, efikasi peribadi guru, keyakinan diri dalam pengajaran, penguasaan kepakaran, kursus dalam perkhidmatan dan program pembangunan profesional. Kedua, rujukan-rujukan yang tersenarai dalam laporan-laporan kajian turut didaftarkan untuk analisis-meta ini. 
Ketiga, satu senarai semak iaitu borang pengkodan digunakan untuk merekod maklumat yang diperlukan daripada setiap artikel yang dipilih. Borang pengkodan ini disesuaikan daripada senarai semak kajian analisis-meta terdahulu (Nordin, 1997). Kandungan borang pengkodan memperincikan definisi setiap variabel secara objektif dan jelas bagi mengurangkan ralat, kesilapan atau ketinggalan. Antara variabel konseptual dan metodologi kajian yang terkandung dalam borang ini ialah nama pengarang, tahun penerbitan, jenis penerbitan, dan tempat kajian dijalankan. Selain itu, borang ini juga digunakan untuk mengkod reka bentuk kajian, saiz dan jenis sampel, sifat penguasaan masteri, instrumen mengukur efikasi kendiri guru, dan statistik ES.

Terdapat beberapa artikel yang melaporkan lebih daripada satu variabel bergantung bagi kajian yang sama. Misalnya, tiga jenis efikasi kendiri guru kerap dilaporkan serentak, iaitu efikasi (i) menggunakan strategi pengajaran, (ii) mendapatkan penyertaan pelajar, dan (iii) mengurus kelas. Analisis-meta ini, walau bagaimanapun hanya mengambil kira satu variabel bergantung sahaja bagi mengelakkan peningkatan ralat. Dalam keadaan ini variabel yang dipilih untuk dianalisis-meta ialah efikasi kendiri guru dalam menggunakan strategi pengajaran. Proses pengkodan dilakukan menerusi aktiviti membaca, mengesan, mencungkil dan mencatatkan maklumat dan data daripada setiap artikel yang telah disenarai pendek. Aktiviti tersebut dilakukan secara berasingan oleh dua orang penyelidik. Perbezaan catatan segera diatasi menerusi perbincangan dan persetujuan antara kedua mereka.

Daripada 16,300 artikel yang diperolehi melalui pencarian kata kunci dalam pelbagai pangkalan data, 121 laporan telah dipilih untuk diteliti. Sampel 121 laporan kajian ini mengandungi pernyataan tentang pengamalan masteri dan efikasi kendiri guru dalam abstrak kajian. Daripada jumlah tersebut, hanya 24 laporan yang memenuhi tujuh kriteria saringan yang dinyatakan terdahulu. Seterusnya mendapati bahawa 24 laporan kajian keratan lintang tersebut mengandungi 26 kajian bebas yang dapat digunakan dalam analisis-meta ini. Jumlah 26 kajian yang dipilih adalah mencukupi untuk menangani metabias yang merupakan ancaman utama yang berpotensi menjejaskan kualiti keputusan analisis-meta (Sterne et al., 2011). 
Jadual 1 menyenaraikan sifat-sifat utama kajian yang digunakan dalam analisis-meta ini. Jumlah guru yang terlibat dalam semua kajian tersebut ialah 10,752 orang, dengan purata 414 guru bagi setiap kajian. Kumpulan guru yang dikaji tergolong daripada guru sekolah rendah (13 kajian), guru sekolah menengah (enam kajian), dan campuran guru sekolah rendah dan sekolah menengah (tujuh kajian). Sementara itu, hanya lapan kajian yang dijalankan di kawasan Asia dan Asia Barat, manakala bakinya 16 kajian lain dilaporkan di negara-negara Barat, khususnya Amerika Utara.

Jadual 1

Kajian-Kajian Efikasi Kendiri Guru untuk Analisis-Meta

\begin{tabular}{|c|c|c|c|c|c|c|c|}
\hline Kajian & $\mathrm{n}$ & Tahun & Sekolah & Negara & Budaya & Kriterion & $\mathrm{p}$ \\
\hline Aldridge \& frase (2016) & 781 & 2015 & Menengah & Australia & Western & SkalaLain & Sig. \\
\hline Britten \& Lai (1998) & 313 & 1998 & Rendah & USA & Western & InstrumenSendiri & NS \\
\hline Cadungog (2015) & 400 & 2015 & Menengah & Philippines & Asian & SkalaLain & Sig. \\
\hline Collie et al. (2012) & 664 & 2012 & Men\&Rendah & Canada & Western & TSES & Sig. \\
\hline Devos et al. (20012) & 110 & 2012 & Rendah & Belgium & Western & InstrumenSendiri & NS \\
\hline Ghanizadeh \& Moafian (2011) & 779 & 2011 & Men\&Rendah & Iran & MidEast & TSES & Sig. \\
\hline Klassen \& Chiu (2010) & 1430 & 2010 & Rendah & Canada & Western & TSES & Sig. \\
\hline Kosko \& Wilkins (2009); S1 & 475 & 2009 & Rendah & USA & Western & InstrumenSendiri & Sig. \\
\hline Kosko \& Wilkins (2009); S2 & 475 & 2009 & Rendah & USA & Western & InstrumenSendiri & Sig. \\
\hline Lee (2013) & 79 & 2013 & Rendah & USA & Western & SkalaLain & NS \\
\hline Malinen et al. (2013) & 867 & 2013 & Men\&Rendah & Finland & Western & SkalaLain & Sig. \\
\hline Mohamadi (2011) & 284 & 2011 & Menengah & Iran & MidEast & TSES & Sig. \\
\hline Nordin (2001) & 140 & 2001 & Menengah & Malaysia & Asian & SkalaLain & Sig. \\
\hline Ransford et al. (2009) & 133 & 2009 & Rendah & USA & Western & SkalaLain & NS \\
\hline Sezgin \& Erdogen (2015) & 600 & 2015 & Rendah & Turkey & MidEast & TSES & Sig. \\
\hline Swackhamer et al. (2009) & 88 & 2009 & Rendah & USA & Western & SkalaLain & NS \\
\hline Tschannen-Moran \& Hoy (2002) & 170 & 2002 & Men\&Rendah & USA & Western & TSES & Sig. \\
\hline Tschannen-Moran \& Johnson (2007); S1 & 74 & 2007 & Men\&Rendah & USA & Western & TSES & Sig. \\
\hline Tschannen-Moran \& Johnson (2007); S2 & 181 & 2007 & Men\&Rendah & USA & Western & TSES & Sig. \\
\hline Tschannen-Moran \& Johnson (2011) & 648 & 2011 & Rendah & USA & Western & TSES & Sig. \\
\hline Tweed (2013) & 124 & 2013 & Rendah & USA & Western & InstrumenSendiri & Sig. \\
\hline Van Acker (2013) & 1484 & 2013 & Men\&Rendah & Netherland & Western & InstrumenSendiri & Sig. \\
\hline Veisi et al. (2015) & 60 & Jul-05 & Menengah & Iran & MidEast & TSES & Sig. \\
\hline Woolfson \& Brady (2009) & 199 & 2009 & Rendah & UK & Western & TSES & Sig. \\
\hline Yenice (2009) & 139 & 2009 & Rendah & Iran & MidEast & SkalaLain & NS \\
\hline Yeo et al. (2008) & 55 & 2008 & Menengah & Singapore & Asian & TSES & NS \\
\hline
\end{tabular}

Nota. Keputusan, 'NS' bermaksud pertalian tidak signifikan daripada segi statistik; 'Sig.'bermaksud pertalian statistik yang signifikan.

Kebanyakan kajian yang meninjau pertalian antara pengalaman masteri dengan efikasi kendiri guru menggunakan instrumen yang diterbitkan oleh Tschannen-Moran \& Hoy (Teacher Efficacy in Instruction scale; TSES) untuk mengukur variabel kriterion, efikasi kendiri guru. Ini diikuti oleh penggunaan instrumen lain atau yang 
diadaptasi dan diterbitkan dalam kajian berkenaan. Instrumeninstrumen itu termasuklah soal selidik yang dicipta oleh Gibson dan Dembo (1984) dan Riggs dan Enoch (1990) (Teaching Mathematics/ Science Efficacy questionnaire). Data juga menunjukkan bahawa terdapat tujuh daripada 26 kajian yang dipilih melaporkan pertalian yang tidak signifikan antara pengalaman menguasai kepakaran dengan efikasi kendiri guru.

\section{Prosedur Analisis}

Bagi membolehkan perbandingan merentas kajian, analisismeta ini menggunakan indeks pekali korelasi Pearson. Dalam keadaan indeks tersebut tidak dilaporkan secara jelas, statistik lain yang berkaitan dengannya diguna dan ditukarkan menjadi indeks korelasi Pearson. Indeks korelasi separa dan indeks beta turut digunakan sebagai ganti indeks korelasi Pearson (Bowman, 2012). Untuk memastikan andaian taburan lazim ES dipatuhi, analisis-meta ini turut menggunakan prosedur transformasi Fisher $z$ ke atas korelasi Pearson menerusi perisian Comprehensive MetaAnalysis (CMA) versi 3. Seterusnya, untuk menguji kesesuaian model moderasi, prosedur regresi-meta telah dilaksanakan (Borenstein, Hedges, Higgins, \& Rothstein, 2009).

Memandangkan bahawa data ES adalah bersumberkan berbagaibagai kajian, analisis-meta memilih untuk menguji model kesanrawak. Sungguhpun begitu, model kesan-tetap turut diambilkira bagi tujuan membuat perbandingan. Untuk mengukur kepelbagaian, iaitu heterogeneiti yang disebabkan oleh ralat persampelan dan perbezaan sebenar ES, analisis-meta ini juga memeriksa statistikstatistik Chochran's $Q$ dan $I^{2}$.

\section{DAPATAN ANALISIS-META}

\section{Kekuatan Kesan (ES) Pengalaman Menguasai Kepakaran ke atas Efikasi Kendiri Guru}

Rajah 1 meringkaskan keputusan-keputusan analisis-meta pertalian antara pengalaman masteri dengan efikasi kendiri guru. Keputusan analisis mendapati bahawa min pekali korelasi yang berwajarkan saiz sample bernilai .291 dengan selang kepercayaan (CI) $95 \%$ antara .197 dengan .380; sementara nilai-z untuk ujian nol ialah 5.85, 
$p=.001$. Semua statistik ini bermaksud bahawa ES bagi pertalian pengalaman masteri dengan efikasi kendiri guru adalah positif dan bernilai lebih besar daripada sifar.

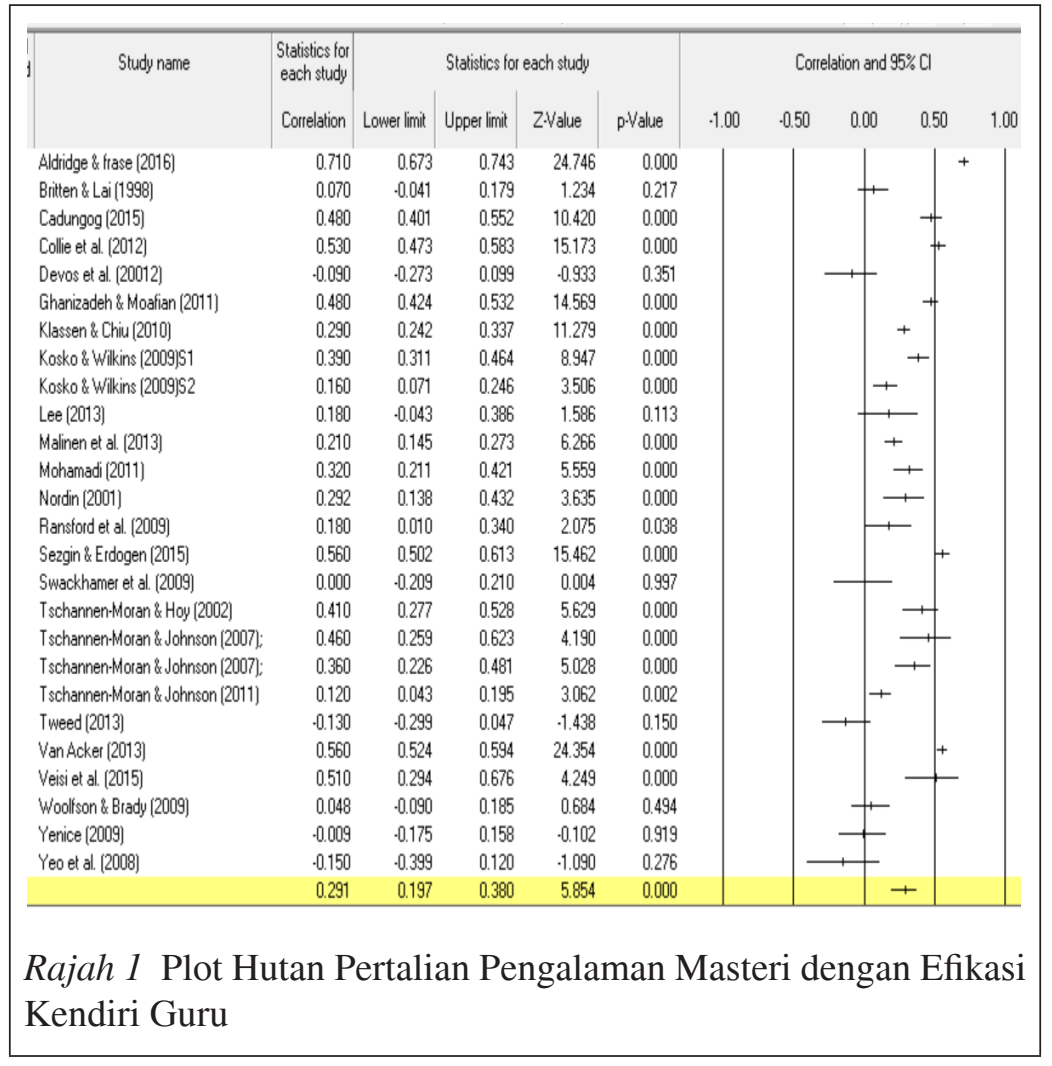

Dapatan ES yang positif, signifikan mengikut statistik dan tidak remeh turut disokong oleh ujian $N$ lulus-gagal. Ujian itu menunjukkan bahawa analisis ini perlu menambah sebanyak 7,330 kajian tidak signifikan lain bagi membatalkan dapatan ES yang positif dan mempunyai nilai praktikal. Tetapi, ujian heterogeneiti Cochran's pula menghasilkan keputusan yang juga signifikan daripada segi statistik; $Q(38)=645.89, p=.001$, manakala indeks $I^{2}$ pula ialah 96.13 . Keputusan ini bermaksud bahawa nilai sebenar ES masih berbeza antara kajian. Perbezaan yang ada ini tidak hanya disebabkan oleh ralat persampelan. Nyata bahawa kajian yang berlainan mempunyai nilai sebenar ES yang berbeza. Dapatan ini juga bertepatan dengan langkah memilih model kesan-rawak sebagai prosedur analisis-meta. 


\section{Sifat Kajian yang Merupakan Moderator ES}

Analisis-meta ini juga bertujuan untuk mengenalpasti samada sifatsifat kajian mempengaruhi ES pengalaman masteri-efikasi kendiri guru. Sifat-sifat yang dapat dikutip daripada semua kajian ialah tahun kajian dijalankan, tahap sekolah, ukuran efikasi kendiri dan lokasi kajian. Untuk itu, satu model regresi telah diuji dengan menggunakan ES pertalian antara pengalaman masteri dengan efikasi kendiri guru sebagai variabel kriterion. Empat sifat kajian diuji sebagai moderator, iaitu variabel peramal dalam model regresi ini.

Keputusan regresi-meta menunjukkan bahawa model regresi yang meramalkan pengaruh sifat kajian ke atas adalah sejajar dengan data yang digunakan. Ujian serentak yang melibatkan semua moderator, kecuali pintasan (intercept) didapati signifikan; $Q(8)=21.55, p=$ $.005, R^{2}=.42$. Keputusan ini bererti bahawa sekurang-kurangnya satu daripada empat sifat kajian mempunyai hubungan sistematik dan boleh dipercayai dengan ES pertalian antara pengalaman masteri dengan efikasi kendiri guru. Namun, nilai sebenar ES tetap tersebar luas walau pun dalam kalangan kajian yang mempunyai sifat yang sama; $Q(17)=208.11, p=.001, I^{2}=91.83$. Pendek kata, sungguhpun model ini dapat mengesan moderator pertalian antara sifat kajian dengan ES, model empat-peramal ES ini masih belum sempurna untuk memerihalkan mengapa ES tersebar secara meluas.

Jadual 2

Keputusan Regresi-Meta ES Pengalaman Menguasai KepakaranEfikasi Kendiri Guru

\begin{tabular}{|c|c|c|c|c|c|c|c|}
\hline \multirow[b]{2}{*}{ Set } & \multirow[b]{2}{*}{ Faktor Peramal } & \multirow[b]{2}{*}{ Beta } & \multirow[b]{2}{*}{ SE } & \multicolumn{2}{|c|}{$95 \%$} & \multirow[b]{2}{*}{ nilai-z } & \multirow[b]{2}{*}{ nilai-p } \\
\hline & & & & Lower & Upper & & \\
\hline & Intercept & -45.62 & 20.87 & -86.52 & -4.71 & -2.19 & 0.03 \\
\hline & Tahun & 0.02 & 0.01 & 0.00 & 0.04 & 2.19 & 0.03 \\
\hline \multirow{2}{*}{ Sekolah } & Sekolah: Men\&Rendah & 0.35 & 0.10 & 0.15 & 0.56 & 3.38 & 0.00 \\
\hline & Sekolah: Menengah & 0.12 & 0.20 & -0.26 & 0.51 & 0.63 & 0.53 \\
\hline \multirow{2}{*}{ DV } & DV: SkalaLain & -0.08 & 0.13 & -0.33 & 0.17 & -0.63 & 0.53 \\
\hline & DV: TSES & -0.05 & 0.12 & -0.28 & 0.18 & -0.42 & 0.67 \\
\hline \multirow{3}{*}{ Lokasi } & Benua: AmerikaUtara & 0.20 & 0.13 & -0.05 & 0.45 & 1.56 & 0.12 \\
\hline & Benua: Asia & 0.37 & 0.26 & -0.14 & 0.87 & 1.43 & 0.15 \\
\hline & Benua: TimurTengah & 0.27 & 0.17 & -0.05 & 0.60 & 1.65 & 0.10 \\
\hline
\end{tabular}


Jadual 2 menunjukkan ringkasan keputusan regresi-meta bagi setiap moderator ke atas ES. Tahun kajian didapati mempunyai pertalian dengan nilai ES; statistik ini bermakna bahawa secara amnya kajiankajian kebelakangan ini mempunyai nilai ES yang lebih tinggi jika dibandingkan dengan kajian-kajian terdahulu.

Sekolah pula merupakan tahap sekolah tempat guru bertugas. Tiga kategori guru dalam analisis-meta ini ialah (i) guru sekolah rendah, (ii) guru sekolah menengah, dan (ii) gabungan guru dari kedua-dua tahap sekolah tersebut. Untuk tujuan regresimeta, dua set perbandingan digunakan, iaitu ES guru sekolah menengah dibandingkan dengan ES guru sekolah rendah, dan ES sampel gabungan berbanding ES guru sekolah rendah. Keputusan regresi-meta menerbitkan pertalian yang signifikan; $Q(2)=11.47, p$ $=.003$. Ini merupakan petanda wujudnya pertalian sistematik antara ES dengan tahap sekolah yang dikaji. Jelas bahawa kajian yang mempunyai sampel gabungan menghasilkan ES yang lebih tinggi jika dibandingkan dengan kajian yang sampelnya terdiri daripada hanya guru sekolah rendah; $\beta=.35$ dengan selang kepercayaan (CI $95 \%) .15, .56 ; z=3.38, p=.01$. Regresi-meta tidak menemukan sebarang perbezaan lain.

\section{KESIMPULAN}

Analisis-meta ini telah menghasilkan beberapa penemuan yang menyumbang kepada pemahaman mengenai pertalian antara pengalaman masteri dengan efikasi kendiri guru. Penemuan pertama nyata menyokong telahan Bandura (1977). Tegasnya terdapat bukti wujudnya pertalian antara dua konstruk tersebut. Pengalaman masteri yang dialami sendiri oleh guru sewaktu menyertai kursus dalam perkhidmatan, melaksanakan tugas pengajaran dan berinteraksi dengan pelajar adalah sumber yang mempengaruhi efikasi kendiri guru. Hubungan kedua konstruk bersifat positif. Pengalaman yang memuaskan mendorong guru untuk merenung, menilai, dan meramal keupayaannya untuk terus mengecapi kejayaan dalam tugas-tugas pembelajaran dan pengajaran. Sebaliknya, kegagalan atau pengalaman yang menyukarkan akan mengekang pemantapan efikasi kendiri guru.

Kedua, tahap ES yang lebih tinggi dikesan dalam kalangan kajian yang menggabungkan sampel guru sekolah menengah dan guru 
sekolah rendah. Apabila guru dari dua tahap sekolah digabungkan, mungkin terbentuk himpunan pengalaman kepakaran yang lebih luas dan mendalam (Swee-Choo et al., 2012). Sampel gabungan kaya dengan cakupan dan kedalaman kepakaran yang dimiliki, jika dibandingkan dengan sampel yang hanya terdiri daripada guru sekolah rendah. Berbeza daripada sampel guru sekolah rendah, sampel gabungan melaporkan keupayaan pada aras yang lebih tinggi dalam membuat pertimbangan, jangkaan dan keyakinan tentang keupayaan dalam mengurus suasana dan proses pembelajaran dan pengajaran (Pajares, 1992).

Di sebalik sumbangan yang ditawarkan menerusi analisis-meta ini, terdapat beberapa batasan yang perlu dinyatakan bagi mewajarkan pemahaman dan tindakan susulan. Tinjauan sistematik mendapati bilangan kajian yang bersifat eksperimental adalah amat terhad. Data yang digunakan dalam analisis-meta ini berasaskan kajiankajian yang menggunakan reka bentuk ex post facto. Reka bentuk ini tidak mempunyai kawalan ke atas persampelan rawak dan ancaman-ancaman tentu sah dalaman lain. Dengan itu, tafsiran pertalian kausal antara faktor penentu efikasi dengan efikasi kendiri guru dilakukan secara longgar, iaitu hanya berasaskan correlational causality. Selain itu, kebanyakan kajian mengenai fenomena efikasi kendiri guru tidak melaporkan dengan lengkap dan nyata sifat-sifat kajian yang diperlukan bagi analisis perbandingan. Misalnya, lebih daripada satu perempat laporan yang dianalisis tidak menyatakan taburan jantina dan tahap pendidikan sampel dalam kajian masingmasing. Ketiadaan maklumat sebegini membataskan keupayaan analisis-meta untuk menguji kesan variabel moderator ke atas ES.

Walau bagaimanapun, analisis-meta ini turut menawar sumbangan kepada amalan pendidikan dan penyelidikan. Keputusankeputusan analisis-meta menunjukkan bahawa guru memerlukan pengalaman masteri bagi kepakaran supaya dapat meningkatkan kompetensi dan profesionalisme. Maksudnya, efikasi kendiri guru dapat ditingkatkan menerusi intervensi, khususnya kursus dalam perkhidmatan. Penemuan analisis-meta ini turut membayangkan bahawa untuk meningkatkan efikasi guru sekolah rendah, kursus dalam perkhidmatan yang dianjurkan wajar melibatkan penyertaan guru sekolah menengah. Di samping itu, adalah dicadangkan supaya kajian-kajian bebas melaporkan maklumat tentang sifat-sifat sampel dan sifat-sifat variabel penentu efikasi kendiri guru dengan 
lebih terperinci. Hal ini dapat dicapai menerusi kerjasama penilai, penyunting dan editor jurnal. Penyelia dan pemeriksa tesis doktor falsafah juga dapat membantu dengan memastikan penyelidik membentangkan maklumat latar belakang sampel yang lengkap.

Akhir kata lebih banyak kajian yang menggunakan reka bentuk eksperimen dan longitudinal diperlukan bagi memahami pertalian punca-akibat antara pengalaman dengan efikasi kendiri guru. Reka bentuk tersebut lebih berupaya untuk menerbitkan keputusan pertalian kausal yang tentu sah. Usaha sedemikian berpeluang untuk meyakinkan pembuat dasar dan pengurus pendidikan guru bertindak meningkatkan kompetensi dan amalan guru di bilik darjah.

\section{RUJUKAN}

Aldridge, J. M., \& Fraser, B. J. (2016). Relationship with teacher self-efficacy and job satisfaction. Learning Environments Research, 19(2), 291-307. https://doi.org/10.1007/s10984015-9198-x

Anderson, R., Greene, M., \& Loewen, P. (1988) Relationships among teachers' and students' thinking skills, sense of efficacy, and student achievement. The Alberta of Journal of Educational Research, 34, 148-165.

Ashton, P.T., \& Webb, R. B. (1986). Making a difference: Teachers' sense of efficacy and student achievement. New York: Longman.

Bandura, A. (1977). Self-efficacy: Toward a unifying theory of behavioral change. Psychological Review, 84, 191-215. https://doi.org/10.1016/0146-6402 (78)90002-4

Bandura, A. (1997). Self-efficacy: The exercise of control. New York: Freeman

Berman, P., McLaughin, M., Bass, G., Pauly, E., \& Zellman, G. (1977). Federal programs supporting educational change: Vol. 7. Factors affecting implementation and continuation. Santa Monica, CA: Rand.

Borenstein, M., Hedges, L. V., Higgins, J. P. T., \& Rothstein, H. R. (2009). Introduction to meta-analysis. Chichester, UK: Wiley

Betoret, F. D. (2006). Stressors, self-efficacy, coping resources, and burnout among secondary school teachers in Spain. 
Educational Psychology, 26, 519-539. http://dx.doi. org/10.1080/01443410500342492

Bowman, N. A. (2012). Effect sizes and statistical methods for metaanalysis in higher education. Res High Educ, 53, 375-382. https://doi.org/10.1007/s11162-011-9232-5

Britten, P., \& Lai, M. K. (1998). Structural analysis of the relationships among elementary teachers. Journal of Nutrition Education, 30(4), 2018-224.

Cantrell, S. C., \& Hughes, H. K. (2008). Teacher Efficacy and Content Literacy Implementation: An Exploration of the Effects of Extended Professional Development with Coaching. Journal of Literacy Research, 40(1), 95-127. https://doi.org/10.1080/10862960802070442

Chester, M., \& Beaudin, B. Q. (1996). Efficacy beliefs of newly hired teachers in urban schools. American Educational Research Journal, 33, 233-257. https://doi. org/10.3102/00028312033001233

Cadungog, M. C. (2015). The mediating effect of professional development on the relationship between instructional leadership and teacher self-efficacy. International Journal of Novel Research in Education and Learning, 2(4), 90-101.

Collie, R. J., Shapka, J. D., \& Perry, N. E. (2012). School climate and social - emotional learning : predicting teacher stress, job satisfaction, and teaching efficacy. Journal of Educational Psychology, 104(4), 1189-1204. https://doi.org/10.1037/ a0029356

Devos, C., Dupriez, V., \& Paquay, L. (2012). Does the social working environment predict beginning teachers' self-efficacy and feelings of depression? Teaching and Teacher Education, 28(2), 206-217. https://doi.org/10.1016/j.tate.2011.09.008

Ghaith, G., \&Yaghi, H. (1997). Relationships among experience, teacher efficacy, and attitudes toward implementation of instructional innovation. Teaching and Teacher Education, 13, 451-458. https://doi.org/10.1016/S0742-051X(96)00045-5

Ghanizadeh, A., \& Moafian, F. (2011). The Relationship between Iranian EFL teachers' sense of self-efficacy and their pedagogical success in language institutes. Asian EFL Journal, 13(2), 249-272. https://doi.org/10.1016/j.system.2009.09.014

Gibson, S., \& Dembo, M. (1984). Teacher efficacy: A construct validation. Journal of Educational Psychology, 76, 569-582. http://dx.doi.org/10.1037/0022-0663.76.4.569 
Goddard, R. D., Hoy, W. K., \& Hoy, a. W. (2000). Collective Teacher Efficacy: Its Meaning, Measure, and Impact on Student Achievement. American Educational Research Journal, 37(2), 479-507. https://doi.org/10.3102/00028312037002479

Greenwood, G. E., Olejnik, S. F., \& Parkay, F. W. (1990). Relationships between four teacher efficacy belief patterns and selected teacher characteristics. Journal of Research and Development in Education, 23(2), 102-106.

Guskey, T. R. (1988). Teacher efficacy, self-concept, and attitudes toward the implementation of instructional innovation. Teaching and Teacher Education, 4, 63-69. http://dx.doi. org/10.1016/0742-051X(88)90025-X

Howardson, G., \& Behrend, T. (2015). The relative importance of specific self-efficacy sources in pretraining self-efficacy beliefs. International Journal of Training and Development, 19(4), 233-252. https://doi.org/10.1111/ijtd.12060

Hoy A. W., \& Davis, H. A. (2006). Teacher self-efficacy and its influence on the achievement of adolescents. In F. Pajares \& T. Urdan (Eds.), Adolescence and education, Vol. 5: Selfefficacy and adolescence (pp. 117-137). Greenwich, CT: Information Age Publishing.

Klassen, R. M., Tze, V. M. C., Betts, S. M., \& Gordon, K. A. (2011). Teacher Efficacy Research 1998-2009: Signs of Progress or Unfulfilled Promise? Educational Psychology Review, 23(1), 21-43. https://doi.org/10.1007/s10648-010-9141-8

Klassen, R. M., \& Chiu, M.M. (2010). Effects on teachers' selfefficacy and job satisfaction: teacher gender, years of experience, and job stress. Journal of Educational Psychology, 102(3), 741-756. https://doi.org/10.1037/a0019237

Klassen, R. M., \& Tze, V. M. C. (2014). Teachers' self-efficacy, personality, and teaching effectiveness: A meta-analysis. Educational Research Review, 12, 59-76. https://doi. org/10.1016/j.edurev.2014.06.001

Kleinsasser, R. C. (2014). Teacher efficacy in teaching and teacher education. Teaching and Teacher Education, 44, 168-179. https://doi.org/10.1016/j.tate.2014.07.007

Kosko, K.K.W., \& Jesse L. M. Wilkins, J. L. M. (2009). General educators' in-service training and their self-perceived ability to adapt instruction for students with IEP. The Professional Educators, 33(2). https://eric.ed.gov/?id=EJ988196 
Lee, S. E. (2013). Professional development and teacher perception of efficacy for inclusion (Doctoral dissertation). East Tennessee State University, USA.

Lipsey, M. W., \& Wilson, D. B. (2001). Practical meta-analysis. Thousand Oaks: Sage.

Lumpe, A., Czerniak, C., Haney, J., \& Beltyukova, S. (2012). Beliefs about Teaching Science: The relationship between elementary teachers' participation in professional development and student achievement. International Journal of Science Education, 34(2), 153-166. https://doi.org/10.1080/0950069 3.2010 .551222

Malinen, O. P., Savolainen, H., Engelbrecht, P., Xu, J., Nel, M., Nel, N., \& Tlale, D. (2013). Exploring teacher self-efficacy for inclusive practices in three diverse countries. Teaching and Teacher Education, 33, 34-44. https://doi.org/10.1016/j. tate.2013.02.004

Martin, M.O., Mullis, I.V.S., Foy, P., \& Stanco, G.M. (2012). TIMSS 2011: International results in science. International Association for the Evaluation of Educational Achievement (IEA).

Midgley, c., Feldlaufer, H., \& Eccles, 1. (1989) Change in teacher efficacy and student self- and task-related beliefs in mathematics during the transition to junior high school. Journal of Educational Psychology, 81, 247-258. https://doi. org/10.1037/0022-0663.81.2.247

Miskel, C., McDonald, D., \& Bloom, S. (1983). Structural and expectancy linkages within schools and organizational effectiveness. Educational Administration Quarterly, 19, 4982. https://doi.org/10.1177/0013161X83019001004

Mohamadi, F. S., Asadzadeh, H., Ahadi, H., \& Jomehri, F. (2011). Testing Bandura's theory in school. Procedia - Social and Behavioral Sciences, 12, 426-435. https://doi.org/10.1016/j. sbspro.2011.02.053

Moore, W. P., \& Esselman, M. E. (1992, April). Teacher efficacy, empowerment, and a focussed instructional climate: Does student achievement benefit? Paper presented at the annual meeting of the American Educational Research Association. San Francisco. [ERIC Reproduction Service No ED350252].

Morris, D. B., Usher, E. L., \& Chen, J. A. (2016). Reconceptualizing the Sources of Teaching Self-Efficacy: a Critical Review of 
Emerging Literature. Educational Psychology Review, 1-39 [online]. https://doi.org/10.1007/s10648-016-9378-y

Nordin, M.S (1997). Elaboration as a text processing strategy: A meta-analytic

Review. RELC Journal, 28, 15-27. https://doi. org/10.1177/003368829702800102

Nordin, M.S. (2001). Sense of efficacy among secondary school teachers in Malaysia. Asia Pacific Journal of Education, 21(1), 66-74. https://doi.org/10.1080/02188791.2001.10594 643

OECD. (2009). Creating effective teaching and learning environments: First results from TALIS, OECD, Paris. Retrieved from http:// www.oecd.org/publishing/corrigenda.

OECD. (2010). TALIS 2008 technical report, OECD, Paris. Available at: www.oecd.org/dataoecd/ 16/14/44978960.pdf (accessed February 7, 2012).

OECD. (2014). TALIS 2013 results: An international perspective on teaching and learning. Paris, OECD Publishing. Retrieved from http://dx.doi.org/10.1787/ 9789264196261-en

Oettigen, G. (1995). Cross-cultural perspectives on self-efficacy. In A. Bandura (Ed.), Self-efficacy in changing societies (pp. 149-176). New York: Cambridge University Press.

Pajares, M. F. (1992). Teachers' beliefs and educational research: Cleaning up a messy construct. Review of Educational Research, 62(3), 307-332. Retrieved from https://doi. org/10.3102/00346543062003307

Pajares, F. (2007). Culturalizing educational psychology. In F. Salili \& R. Hoosain (Eds.), Culture, motivation, and learning (pp. 19-42). Charlotte: Information Age. Retrieved from https:// doi.org/10.1111/bjep.12106

*Ransford, C. R., Greenberg, M. T., Domitrovich, C. E., Small, M., \& Jacobson, L. (2009). The role of teachers' psychological experiences and perceptions of curriculum supports on the implementation of a social and emotional learning curriculum. School Psychology Review, 38(4), 510-532.

Riggs, I. M., \& Enochs, L. G. (1990). Toward the development of an elementary teacher's science teaching efficacy belief instrument. Science Education, 74, 625-637. Retrieved from https://doi.org/10.12691/education-2-4-9

Ross, 1. A. (1992) Teacher efficacy and the effect of coaching on student achievement. Canadian Journal of Education, 17, 5156. 
Ross, J., \& Bruce, C. (2007). Professional development effects on teacher efficacy: Results of randomized field trial. The Journal of Educational Research, 101(1), 50- 60. https://doi. org/10.3200/JOER.101.1.50-60

Ross, J., \& Cousins, J. B. (1993). Enhancing secondary school students' acquisition of correlational reasoning skills. Research in Science \& Technological Education, 11 (3), 191206. http://dx.doi.org/10.1080/0263514930110208

Salomon, G. (1984). Television is "easy" and print is "tough": The differential investment of mental effort in learning as a function of perceptions and attributions. Journal of Educational Psychology, 76, 647-658. https://doi.org/10.1037/00220663.76.4.647

*Sezgin, F., \& Erdogan, O. (2015). Academic optimism, hope and zest for work as predictors of teacher self-efficacy and perceived success. Educational Science: Theory \& Practice, 15(1), 7-19. https://doi.org/10.12738/estp.2015.1.2338

Sharma, U., Loreman, T., \& Forlin, C. (2012). Measuring teacher efficacy to implement inclusive practices. Journal of Research in Special Educational Needs, 12(1), 12-21. https:// doi.org/10.1111/j.1471-3802.2011.01200.x

Shoji, K., Cieslak, R., Smoktunowicz, E., Rogala, A., \& Benight , C.C, \& Luszczynska, A. (2015). Associations between job burnout and self-efficacy: A meta-analysis. Anxiety, Stress, \& Coping. Online article: http://dx.doi.org/10.1080/10615806.2 015.1058369

Soodmand, H., Rahimi, A., Ghonchehpour, A., \& Saedpanah, E. (2015). The Impact of Teaching Experience on Iranian EFL Teachers' Sense of Efficacy and their Perception of English Teacher Distinctive Characteristics. Procedia - Social and Behavioral Sciences, 192, 714-719. https://doi.org/10.1016/j. sbspro.2015.06.069

* Swackhamer, L. E., Koellner, K., Basile, C., \& Kimbrough, D. (2009). Increasing the self-efficacy of inservice teachers through content knowledge. Teacher Education Quarterly, 36(2), 63-78. https://eric.ed.gov/?id=EJ857476

Swee-Choo, P.G., Kung-Teck, W., \& Osman, R. (2012). Studentteachers' approaches to learning, academic performance and teaching efficacy. Malaysian Journal of Learning and Instruction, 9, 31-46.

Torres, A. C. (2016). Teacher Efficacy and Disciplinary Expectations in Charter Schools: Understanding the Link to Teachers' 
Career Decisions. Journal of School Choice, 10(2). https:// doi.org/10.1080/15582159.2016.1152528

Trentham, L. Silvern, S., \& Brogdon, R. (1985). Teacher efficacy and teacher competency ratings. Psychology in the Schools, 22, 343-352. https://doi.org/10.1002/15206807(198507)22:3<343

Tschannen-Moran, M., Hoy, A. W., \& Hoy, W. K. (1998). Teacher efficacy: its meaning and measure. Review of Educational Research, 68, 202-248. https://doi. org/10.3102/00346543068002202

Tschannen-Moran, M., \& Hoy, A. W. (2002, April). The influence of resources and support on teachers' efficacy beliefs. Annual Meeting of the American Educational Research Association. New Orleans, LA, 1-8. Retrieved from http:// anitawoolfolkhoy.com/pdfs/aera-2002-megan.pdf

Tschannen-Moran, M., \& Hoy, A. W. (2007). The differential antecedents of self-efficacy beliefs of novice and experienced teachers. Teaching and Teacher Education, 23(6), 944-956. https://doi.org/10.1016/j.tate.2006.05.003

Tschannen-Moran, M., \& Johnson, D. (2011). Exploring literacy teachers' self-efficacy beliefs: Potential sources at play. Teaching and Teacher Education, 27(4), 751-761. https:// doi.org/10.1016/j.tate.2010.12.005

Van Acker, F., van Buuren, H., Kreijns, K., \& Vermeulen, M. (2013). Why teachers use digital learning materials: The role of self-efficacy, subjective norm and attitude. Education and Information Technologies, 18(3), 495-514. https://doi. org/10.1007/s10639-011-9181-9

Veisi, S., Azizifar, A., Gowhary, H., \& Jamalinesari, A. (2015). the relationship between iranian efl teachers ' empowerment and teachers ', self-efficacy. Procedia - Social and Behavioral Sciences, 185, 437-445. https://doi.org/10.1016/j. sbspro.2015.03.362

Woolfson, L. M., \& Brady, K. (2009). An investigation of factors impacting on mainstream teachers' beliefs about teaching students with learning difficulties. Educational Psychology, 29(2), 221-238. https://doi.org/10.1080/01443410802708895

Yenice, N. (2009). Search of science teachers' teacher efficacy and self-efficacy levels relating to science teaching for some variables. Procedia - Social and Behavioral Sciences, 1(1), 1062-1067. https://doi.org/10.1016/j.sbspro.2009.01.191 
Yeo, L. S., Ang, R. P., Chong, W. H., Huan, V. S., \& Quek, C. L. (2008). Teacher efficacy in the context of teaching low achieving students. Current Psychology, 27(3), 192-204. https://doi.org/10.1007/s12144-008-9034-x

Yoo, J. H. (2016). The effect of professional development on teacher efficacy and teachers' self-analysis of their efficacy change. Journal of Teacher Education for Sustainability, 18(1), 8494. https://doi.org/10.1515/jtes-2016-0007

Zee, M., \& Kooman, H. M. Y. (2016). Teacher self-efficacy and its effects on classroom processes, student academic adjustments, and teacher well-being: a synthesis of 40 years of research. Review of Educational Research. https://doi. org/10.3102/0034654315626801

*Kajian yang digunakan dalam analisis-meta 